\title{
The Scale and Characteristics of Services Offshoring in the Visegrád Countries
}

\author{
Magdalena Myszkowska
}

\begin{abstract}
A B S T R A C T
Objective: The paper aims to outline the current position of V4's as destinations for services offshoring activities, analyse the extent and patterns of service exports and service-based FDI, and to determine their potential as offshoring locations.

Research Design \& Methods: The paper is divided into six sections. Following the introduction, the 2 nd section provides the theoretical background and gives an overview of the definitions of services offshoring. The 3rd and 4th sections examine trade data in order to find evidence of enhanced offshoring-related service activities in V4's. The 5th section studies the current and future position in the global services offshoring market of the CEECs. The final section contains research conclusions.
\end{abstract}

Findings: In the last few years, the CEECs have become an important location for services offshoring; there has been significant growth in the participation of this region in the global services offshoring market. Trade statistics confirm the assumption that expanding export in other business services and ICT services was associated with the growing importance of the $\mathrm{V} 4$ countries as offshoring locations.

Implications \& Recommendations: Service offshoring is already a large and fastgrowing industry in V4's, and there are emerging opportunities for extending it even further, individually and as a group, building on their past successes in exports. The main threats that V4's face are related to other CEECs that will seek to penetrate further into the nearby Western European market.

Contribution \& Value Added: The results will contribute to the increase of knowledge of the society about one of the most crucial processes in the contemporary global economy. It is expected that offshoring will spread, embracing new and more advanced business processes. Hence, this phenomenon demands further analyses.

\begin{tabular}{|c|c|}
\hline Article type: & research paper \\
\hline Keywords: & $\begin{array}{l}\text { Central and Eastern Europe (CEE); international outsourcing; } \\
\text { offshoring; service-based FDI; service trade; Visegrád countries (V4) }\end{array}$ \\
\hline JEL codes: & F14 \\
\hline Received: 12 & Revised: 17 March 2014 \\
\hline
\end{tabular}

\section{Suggested citation:}

Myszkowska, M. (2014). The Scale and Characteristics of Services Offshoring in the Visegrád Countries. Entrepreneurial Business and Economics Review, 2(3), 33-46. 


\section{INTRODUCTION}

The relocation of services is a phenomenon parallel to the phenomenon of relocating industrial processes from developed to developing countries with low operational cost. Central and Eastern European (CEE) countries play an important role in both types of relocation processes. In the last couple of years, relocation processes experienced rapid growth; a trend especially noticeable in the case of the new EU member states from the CEE, which began to act as host for this type of investments. However, their share in attracting such activities has been dwarfed by China in manufacturing and by India and certain developed countries, such as Ireland, Canada, and Israel, in services.

Knowledge of the development of services offshoring is limited, as a result of the lack of appropriate data and research tools. There is no doubt, however, that - especially after 2000 - production, value-added, employment, foreign direct investments and export levels rose noticeably in the CEE countries (in particular in the Czech Republic, Poland, Romania and Slovakia) as a result of offshoring.

As there are no readily available statistical indicators for measuring the extent of services offshoring in the V4 or the relative position of the countries in this process, the analysis is based on indirect measures. Following a widely applied methodology (UNCTAD, 2004), two service categories are suitable for evaluating the size of trade in offshorable services: 'computer and information services' and 'other business services.' Their sum is assumed to cover the great variety of services that may potentially be affected by offshoring.

This attempt at estimating the scale of offshoring is based on a three-tier approach. Firstly, on the basis of the balance of payments (BOP) statistics, the occurring trends in relation to the size and structure of the services sector that can result from increased levels of offshoring were identified. An assumption was made that an increase of service export levels in the host country is a consequence of the fact that a positive decision regarding relocation has been made. Trade data derived from the BOP statistics gives a good approximation allowing the identification of trends in those services that can be regarded as offshorable ${ }^{2}$, helps identify the geographical direction of relocation processes within the region, and also highlights the shifts in country level performance in terms of attracting offshored services.

Secondly, services offshoring data for the V4 countries will be extracted from the available official foreign direct investment (FDI) statistics, especially since according to estimates, so-called captive offshoring amounts to about two-thirds of the total value of offshoring worldwide. Traditionally, FDI is categorized either as horizontal (demand/market driven) or vertical ${ }^{3}$ (cost driven). Market-seeking investors establish a subsidiary in the host country to provide services for the local market and are usually attracted by specific market attributes. For vertical investors, the most important motive

\footnotetext{
${ }^{1}$ These two categories are also referred to as 'IT services' and 'ITC-enabled services', respectively.

2 Since the BOP statistics also contain services other than those subject to offshoring, the data they contain should be treated as indicating the upper level of the phenomenon (WTO, 2005).

${ }^{3}$ Vertical investments are relatively new phenomenon within service sector and result mainly from the advances in technology, which made the fragmentation of the value chain possible.
} 
of investing abroad is taking advantage of the local resources. These companies offshore only particular service functions - usually administration (back office functions), finance, human resources, payroll services, logistics, customer care, knowledge services and R\&D. Such investments are commonly referred to as shared service or contact centres. ${ }^{4}$

In the case of vertical investment, the majority of the services are immediately exported. These services are highly export-oriented and their export intensity is also very high (around 100\%). That is why trade data gives the most relevant proxy for calculating the extent of the offshoring of these activities. Therefore, the growth of vertical investments in the service sector also leads to increased export levels for services (Gal, 2013).

Determining the actual extent and patterns of service offshoring requires a combination of quantitative and qualitative research. Hence, the statistical data is augmented with data from alternative sources (mostly expert analyses), which can be useful in spotting new phenomena that are not yet picked up by official statistics or that are being picked up with great delay.

\section{THEORETICAL BACKGROUND}

There have been many attempts at defining offshoring, hence one is bound to discover some differences between them when analysing the subject. Since offshoring is often treated coextensively with outsourcing, it is important to always precisely define these two notions and the relations between them. In practice, to simplify matters, the dominant approach in the literature is to categorise the main notions and their synonyms, taking into account the location (inside or outside a country) and the ownership of production resources (insource - outsource). The scope and type of offshoring and outsourcing are often defined additionally, resulting in notions such as nearshoring, concurrent sourcing, multisourcing or backshoring/deoffshoring.

In this paper, the definition from the World Investment Report (UNCTAD, 2004) is used (Table 1), which defines offshoring as the transfer and localisation of a part of a business process outside the country to the places where these can be serviced by foreign divisions of the company (captive offshoring, intra-firm offshoring) or by independent companies (offshore outsourcing). The notions of captive offshoring and offshore outsourcing relate to the company's decision of selecting a subset of the services they offer and relocating these to their foreign division (affiliated trade) or to a third-party provider abroad (unaffiliated trade), respectively.

Offshoring and outsourcing are also defined as trade phenomena that describe the directions of the trade flow (Table 2). There are three scenarios when offshoring can occur (Małuszyńska, 2013):

1. The company partially relocates services to its foreign divisions (Arrow 1).

\footnotetext{
${ }^{4}$ Shared service centres usually deal with back office and corporate functions supporting subsidiaries of the company abroad. Contact centres on the other hand deal with front office - customer facing - activities and serve the customers either within a particular region or globally.
} 
2. The company that has been outsourcing its services to a third-party service provider (Arrow 2) in the home country changes the provider to a foreign one (Arrow 3).

3. The company decides to relocate production to an independent company abroad (Arrow 4).

Table. 1 Offshoring and outsourcing permutations

\begin{tabular}{|c|c|c|}
\hline $\begin{array}{l}\text { Location of } \\
\text { production }\end{array}$ & Internalized production & $\begin{array}{l}\text { Externalized production } \\
\text { „OUTSOURCING" }\end{array}$ \\
\hline Home country & $\begin{array}{l}\text { Production kept in-house at } \\
\text { home }\end{array}$ & $\begin{array}{l}\text { Production outsourced to a third-party service } \\
\text { provider at home }\end{array}$ \\
\hline $\begin{array}{l}\text { Foreign country } \\
\text { „OFFSHORING” }\end{array}$ & $\begin{array}{l}\text { Production by foreign } \\
\text { division/affiliate } \\
\text { (intra-firm/captive offshoring) }\end{array}$ & $\begin{array}{l}\text { Production outsourced to third-party provider } \\
\text { abroad, which can be: } \\
\text { a local company, } \\
\text { a foreign affiliate of another TNC } \\
\text { (offshore outsourcing) }\end{array}$ \\
\hline
\end{tabular}

Source: (UNCTAD, 2004).

Table 2. Trade flow: outsourcing and offshoring

\begin{tabular}{|c|c|}
\hline \multicolumn{2}{|c|}{ Location } \\
\hline Domestic & Overseas \\
\hline $\begin{array}{c}\text { Supply within the company } \\
\text { Domestic Divisions/Affiliates }\end{array}$ & $\begin{array}{c}\text { Supply outside the company } \\
\text { (FDI and Intra-firm Trade) }\end{array}$ \\
\hline Source from Domestic Suppliers & S Source from Foreign Suppliers \\
\hline International Trade
\end{tabular}

Source: adopted from (Sako, 2005, p. 6) quoted in (Małuszyńska, 2013, p. 22).

Captive offshoring and outsource offshoring, as integral elements of the process of production fragmentation, are considered to be certain forms/types of (re)location, understood as the transfer of a part of services between countries, manifesting itself as direct international investment flows and international service flows within one organisation or between unaffiliated companies with separate capitals ${ }^{5}$ (Radło, 2006).

\footnotetext{
${ }^{5}$ Without an indication whether or not it is accompanied by stopping or limiting production or downsizing in the country of origin.
} 
From the point of view of the type of the relocated services, we can distinguish inter alia:

1. information technology offshoring (ITO) - covering the process of creating, support, programming, security and the processing of business transactions,

2. business process offshoring (BPO) - covering services related to business processes, that is, finance and accounting services, human resources, legal services, analytic services, market analysis, data processing, etc.; if the business processes require specialized knowledge such as legal advice or market analysis, the offshoring of such services is often described as knowledge process offshoring - (KPO).

It is important to note that services offshoring is a very dynamic process, in which the list of services considered to be viable for relocation grows rapidly. However, this also means that the research and statistics in the field are quickly becoming outdated.

\section{SERVICE EXPORTS OF THE V4 COUNTRIES}

When analysing the current service trade patterns of the CEE countries, it is of utmost importance to remember that the starting level for these countries' growth was very low. The previous economic system left the region with huge structural imbalances and a severely depressed service sector. Consequently, a wide range of services, particularly business-related ones, were either non-existent or not developed according to Western standards (Ghibutiu \& Poladian, 2009).

The export of services has grown significantly in the V4 region since 2002 (Figure 1). In comparison to 1995, the level of service exports tripled in 2008. The share of the V4 in global service exports is modest $\left(2,09 \%\right.$ in $\left.2012^{6}\right)$, illustrating the still-low service export capabilities of these countries, although their growth rate is higher than the global or EU average. In absolute terms, Poland is the top service exporter (37897 $\mathrm{mln}$ USD), followed by the Czech Republic ( $22106.32 \mathrm{mln}$ USD), Hungary (20392.12 mln USD) and Slovakia (7158.07 $\mathrm{mln}$ USD). When measuring their services trade integration as a percentage of $\mathrm{GDP}^{7}$, Hungary is the country with the highest level of this indicator $(14.5 \%)$, while Poland is the lowest $(7.1 \%)^{8}$.

The majority of V4 exports in services are directed at the EU market (around 70\%) which suggests that centres provide services mainly for their customers or subsidiaries in Europe (Fifekova \& Hardy, 2010).

The V4 countries are now not only exporting more traditional services, such as transportation and travel, but also more modern and skill-intensive services, such as financial intermediation, computer and information services, and legal and technical support. Skilled jobs performed by accountants, programmers, designers, architects,

\footnotetext{
${ }^{6}$ In the individual V4, the respective shares ranged between $0.17 \%$ in Slovakia and $0.9 \%$ in Poland.

${ }^{7}$ This indicator has the advantage of removing the effect of differences in the size of the V4 countries.

${ }^{8}$ Figures provided on the bases of the data of Eurostat BOP Statistics retrieved on January 4, 2014 from: <http://epp.eurostat.ec.europa.eu/portal/page/portal/balance_of_payments/data/database>.

${ }^{9}$ EU-15 customers purchased $57 \%$ of CEE service exports in 2010.
} 
medical diagnosticians, and financial and statistical analysts are increasingly outsourced by firms in developed countries.

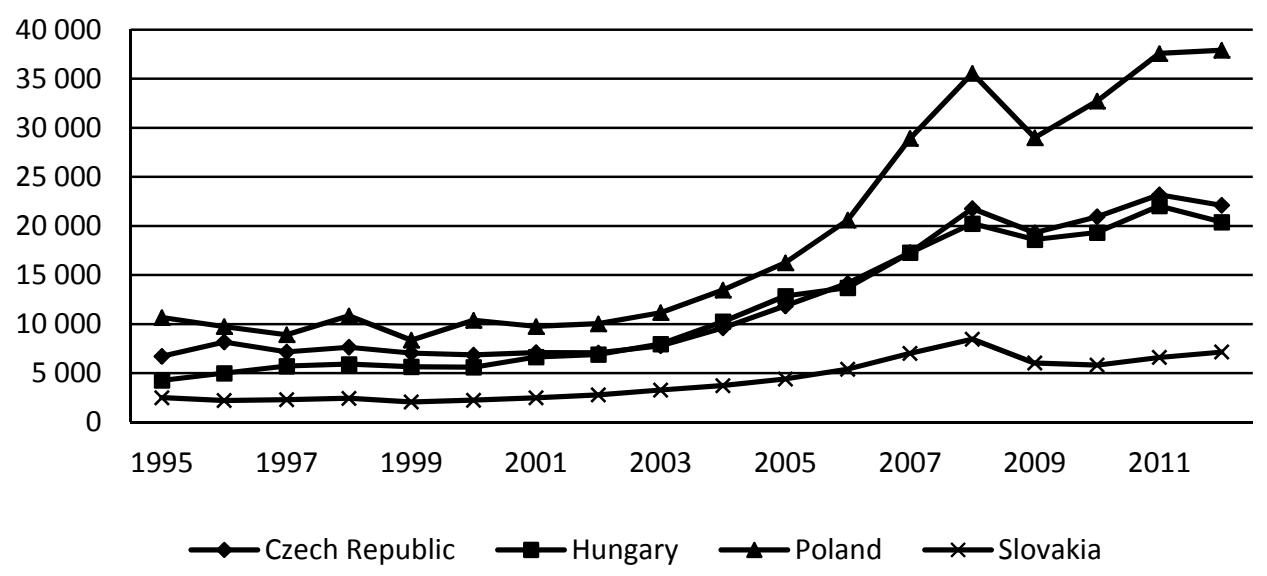

Figure 1. Total services exports of the V4 countries in the years 1995 - 2012 (in $\mathrm{mln}$ USD) Source: OECD Statistics retrieved on January 18, 2014 from: http://stats.oecd.org/index.aspx?queryid=166

The striking fact about the sector share of service exports in the V4 countries is that traditional services still dominate over all other services (including offshorable services). Over $60 \%$ of service exports relate to travel and transportation, followed by business services. Out of these three sectors, the growth rate of business service exports was the most dynamic one (Table 3).

Table 3. The structure of services exports in the V4 in the years 2004, 2008 and 2012 (in \%)

\begin{tabular}{|l|r|r|r|r|r|r|r|r|r|r|r|r|r|}
\hline \multirow{2}{*}{ Industries } & \multicolumn{3}{|c|}{ Czech Republic } & \multicolumn{3}{|c|}{ Hungary } & \multicolumn{3}{|c|}{ Poland } & \multicolumn{3}{|c|}{ Slovakia } \\
\cline { 2 - 13 } & $\mathbf{2 0 0 4}$ & $\mathbf{2 0 0 8}$ & $\mathbf{2 0 1 2}$ & $\mathbf{2 0 0 4}$ & $\mathbf{2 0 0 8}$ & $\mathbf{2 0 1 2}$ & $\mathbf{2 0 0 4}$ & $\mathbf{2 0 0 8}$ & $\mathbf{2 0 1 2}$ & $\mathbf{2 0 0 4}$ & $\mathbf{2 0 0 8}$ & $\mathbf{2 0 1 2}$ \\
\hline Total services & 100.0 & 100.0 & 100.0 & 100.0 & 100.0 & 100.0 & 100.0 & 100.0 & 100.0 & 100.0 & 100.0 & 100.0 \\
\hline Other business services & $\mathbf{1 5 . 6}$ & $\mathbf{2 5 . 5}$ & $\mathbf{2 5 . 6}$ & $\mathbf{2 4 . 1}$ & $\mathbf{2 8 . 3}$ & $\mathbf{3 1 . 4}$ & $\mathbf{1 3 . 9}$ & $\mathbf{2 2 . 7}$ & $\mathbf{2 6 . 2}$ & $\mathbf{1 6 . 7}$ & $\mathbf{1 7 . 2}$ & $\mathbf{2 1 . 4}$ \\
\hline Computer and information & $\mathbf{1 . 3}$ & $\mathbf{6 . 7}$ & $\mathbf{9 . 3}$ & $\mathbf{3 . 4}$ & $\mathbf{5 . 8}$ & $\mathbf{6 . 3}$ & $\mathbf{1 . 9}$ & $\mathbf{2 . 5}$ & $\mathbf{6 . 5}$ & $\mathbf{3 . 3}$ & $\mathbf{3 . 4}$ & $\mathbf{7 . 1}$ \\
\hline Transport & 28.6 & 24.8 & 23.3 & 12.6 & 19.6 & 21.4 & 31.5 & 31.0 & 29.6 & 40.0 & 34.5 & 28.6 \\
\hline Travel & 44.2 & 35.6 & 32.0 & 36.8 & 29.7 & 23.9 & 42.6 & 33.1 & 28.9 & 23.3 & 31.0 & 32.1 \\
\hline Financial & 3.9 & 0.7 & 0.0 & 2.3 & 1.4 & 0.6 & 0.9 & 1.7 & 1.0 & 3.3 & 1.7 & 0.0 \\
\hline Communications & 2.6 & 2.7 & 2.3 & 2.3 & 2.9 & 1.3 & 1.9 & 1.7 & 1.4 & 3.3 & 3.4 & 1.8 \\
\hline Personal, cultural recreation & 2.6 & 0.7 & 1.2 & 10.3 & 5.1 & 6.9 & 0.9 & 0.4 & 1.0 & 3.3 & 1.7 & 1.8 \\
\hline Construction & 1.3 & 2.0 & 3.5 & 1.1 & 2.9 & 1.9 & 4.6 & 5.4 & 3.7 & 3.3 & 1.7 & 3.6 \\
\hline Insurance & 0.0 & 0.7 & 1.2 & 0.0 & 0.0 & 0.0 & 0.9 & 0.4 & 1.0 & 0.0 & 0.0 & 0.0 \\
\hline Royalties and licence fees & 0.0 & 0.0 & 1.2 & 4.6 & 4.3 & 5.7 & 0.0 & 0.8 & 0.7 & 0.0 & 1.7 & 0.0 \\
\hline Government services & 0.0 & 0.0 & 0.0 & 1.1 & 0.7 & 0.6 & 0.0 & 0.4 & 0.0 & 0.0 & 0.0 & 0.0 \\
\hline Services not allocated & 0.0 & 0.7 & 0.6 & 1.1 & 0.0 & 0.0 & 0.9 & 0.0 & 0.0 & 3.3 & 3.4 & 3.6 \\
\hline
\end{tabular}

Source: Own calculation based on Eurostat BOP Statistics retrieved on January 4, 2014 from

http://epp.eurostat.ec.europa.eu/portal/page/portal/balance_of_payments/data/main_tables

The data collected from Eurostat BOP Statistics illustrates the increased tradability and large export intensity of the so-called offshorable services, i.e. business services and computer and information services. Between 2001 and 2012, their share within total 


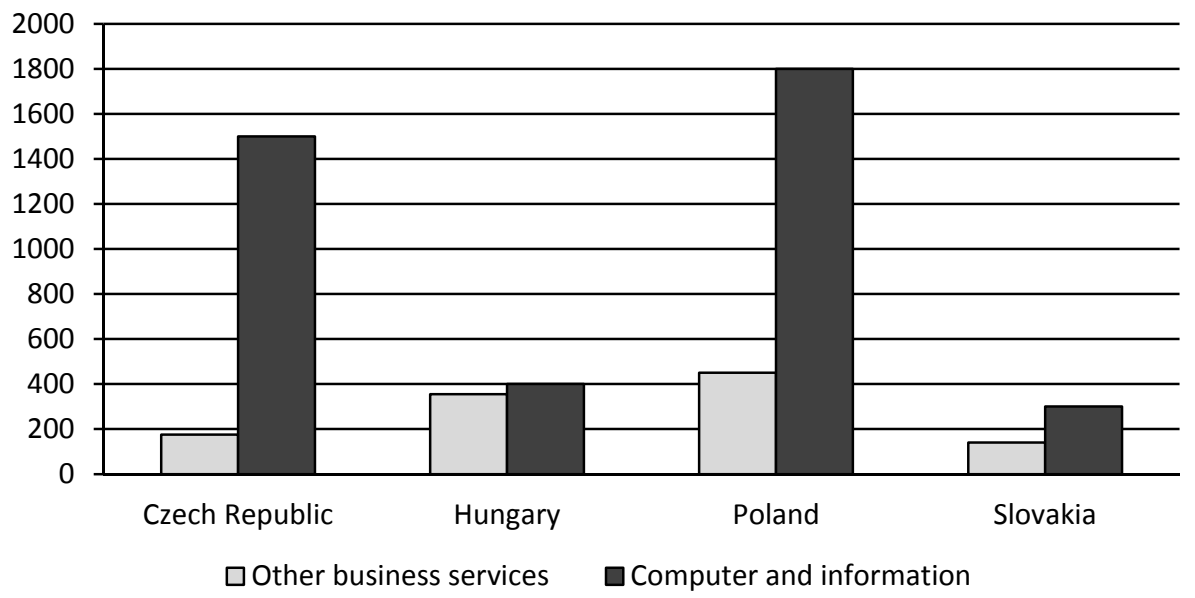

Figure 2. The growth of offshorable service exports in the V4 in the years 2001-2012 (in \%)

Source: own calculation based on Eurostat BOP Statistics retrieved on January 4, 2014 from http://epp.eurostat.ec.europa.eu/portal/page/portal/balance_of_payments/data/main_tables

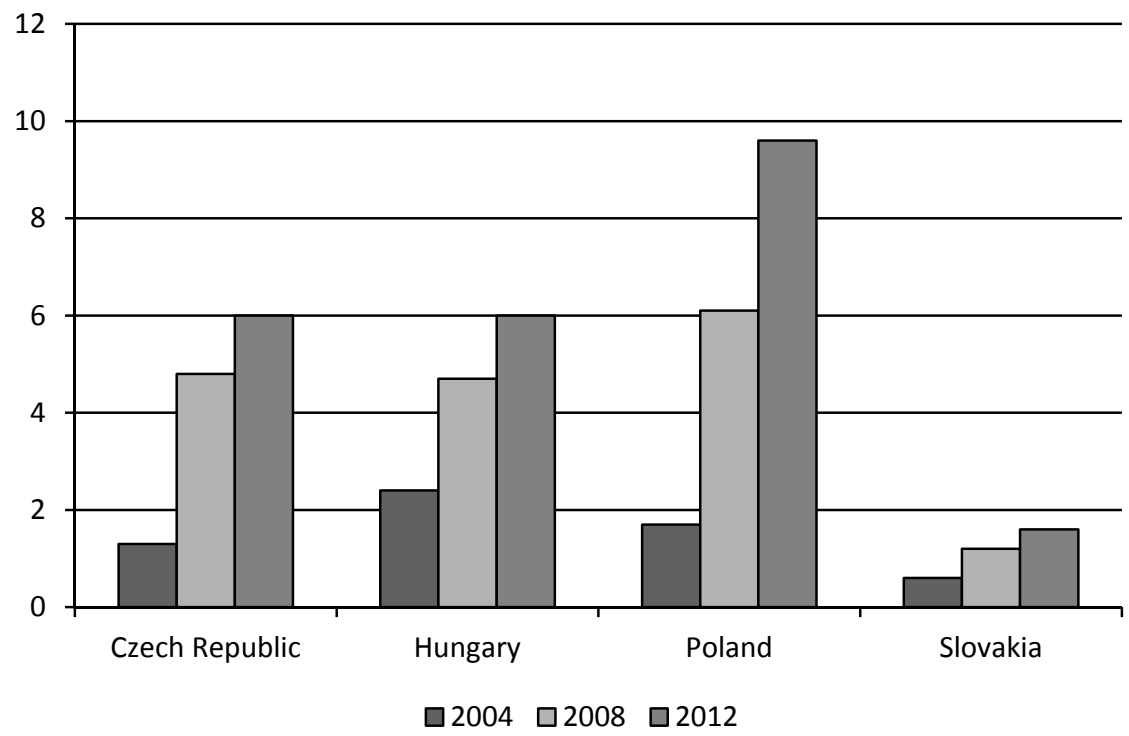

Figure 3. The offshorable service exports in the V4 in the years 2004, 2008 and 2012 (in 1000 mln EUR)

Source: Eurostat BOP Statistics retrieved on January 4, 2014 from

http://epp.eurostat.ec.europa.eu/portal/page/portal/balance_of_payments/data/main_tables

service exports grew steadily from $17.5 \%$ to $34 \%$. It should be noted that Poland and the Czech Republic experienced the highest growth (see Figure 2). 
The total value of these two service subcategories in the V4 was equal to $23.2 \mathrm{mld}$ EUR in 2012. The overwhelming dominance of business services (an average of $85.3 \%$ ) in the period 2001-2012 is striking. In absolute terms, Poland is the largest trader, followed by Hungary and Czech Republic (Figure 3).

The above service trade statistics support the preliminary assumption that offshoring generates expanding exports in particular service categories, namely business services and computer and information services. However, it is obvious that not all kinds of trade are connected to the offshorable services. The data does not show the true extent to which the offshorable service exports are provided by offshorable service centres, nor do they distinguish between the different forms of offshoring (Gal, 2013).

\section{SERVICE-RELATED FOREIGN DIRECT INVESTMENT IN CEE}

In the CEE countries, the range of services expanded rapidly as a result of the ongoing economic transformation; all this happened in alignment with the worldwide structural shift towards service-based foreign direct investment. In the Czech Republic, Hungary and Poland, foreign investments in the service sector became dominant by the late 1990s, but the boom started in 2000, when service-related FDI reached almost $60 \%$ of the total FDI in the region (Figure 4). Since 2000, the share of service sector FDI in total FDI flows was $70 \%$ in the Czech Republic, 55\% in Hungary, $60 \%$ in Poland and $40 \%$ in Slovakia. Overall, the tertiary sector received more than $60 \%$ of the foreign capital inflows into the V4 region (Fifekova \& Hardy, 2010).

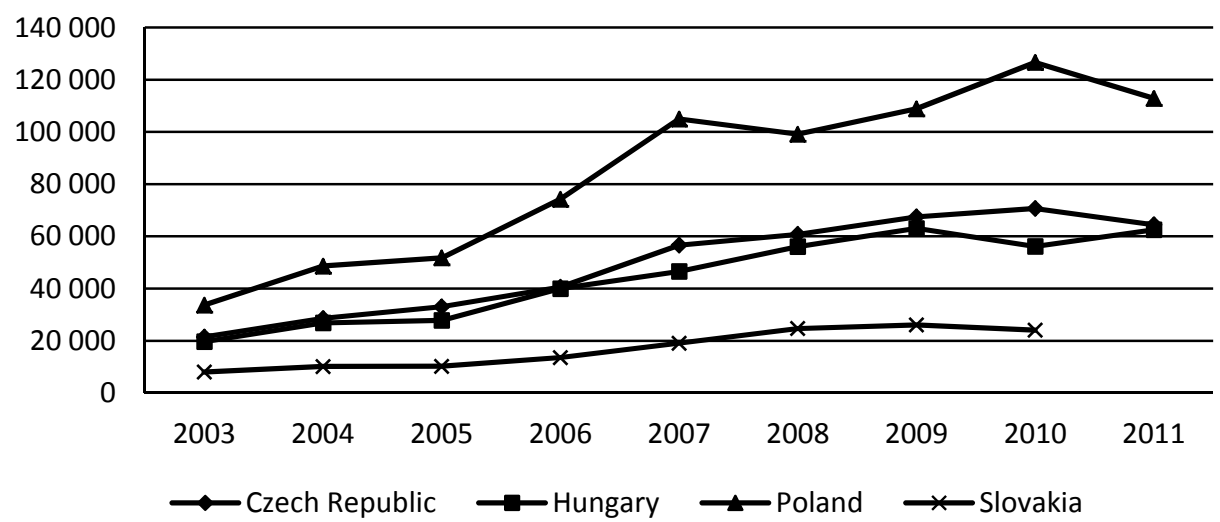

Figure 4. Service sector FDI stocks in the V4 countries in the years 2003-2011 (in mln EUR) Note: data from 2011 for Slovakia were not available.

Source: OECD Statistics retrieved on January 20, 2014 from http://stats.oecd.org/Index.aspx?Data SetCode=FDI_FLOW_INDUSTRY

The structure of service-related FDI in CEE countries reoriented in line with international trends. From 1990 onward, the huge unsaturated service markets and lack of competition in CEE countries constituted an opportunity for horizontal investments, even though the political situation was unstable and the business environment 
unfavourable $^{10}$. In the first decade of the transformation ${ }^{11}$, the majority of incoming service FDI was concentrated in trade, transport, communication, financial intermediation, real estate, business activities and other infrastructure services (Fifekova \& Hardy, 2010).

After 2000, the composition of FDI flows started to change; there has been a shift from markets seeking horizontal business service investments to vertical business service investments. Divergence from the traditionally dominant FDI receiving service sectors was compensated for by the increasing share of investments into business activities, which can be observed especially in case of the Czech Republic and Poland (Fifekova \& Hardy, 2010). As a result of the changing composition of FDI, the V4 countries have found themselves competing with other destinations to attract business services with high value-added activities.

The first business service projects in the CEE region mainly involved so-called backoffice functions (finance, invoicing), which are less complicated and do not involve direct contact with the client. In the next stage, front office (customer facing) activities were transferred to the region, and the process continues with more value-added and skillintensive activities. While Poland, Hungary and Slovakia attract a wide range of service activities, investments in the Czech Republic mainly specialise in IT-related activities (Sass \& Fifekova, 2011).

The Czech Republic and Hungary are the group leaders when it comes to attracting service FDI. Poland, owing mainly to its size, usually surpasses all the other countries in terms of absolute FDI inflow, but nevertheless usually falls behind when per capita terms are taken into consideration. Slovakia lags behind in terms of both absolute and relative service sector FDI inflows and attracts the least amount of high value-added investment among the V4 countries (Sass \& Fifekova, 2011).

The share of V4 countries in the global business services FDI is very low. The region is lagging far behind Asia (India being its powerhouse in that respect) and Western Europe, but it shows growing potential. It seems justifiable that service investments in the V4 countries are driven by the foreign investor's desire to gain access to skills and a business environment comparable to home country conditions, while taking advantage of relatively lower operational costs (Fifekova \& Hardy, 2010).

\section{THE GROWING IMPORTANCE OF CEE COUNTRIES IN THE GLOBAL OFFSHORING MARKET}

Globally, the offshoring industry is expected to grow by $10 \%$ annually through 2020, reaching 1.6 billion USD (1.3 billion EUR) annually (McKinsey Global Institute, 2013). By 2011, IT and business services in the form of captive offshoring and offshore

\footnotetext{
${ }^{10}$ The investment incentives were not aimed at services companies at that time as the government realized that these firms are entering the market anyway being driven by market access rather than decreasing costs.

${ }^{11}$ A shift from centrally-planned economy towards market economy required an introduction of various previously unavailable - services to satisfy the market needs. In the first years of transition, a wide range of service categories could not be provided locally, due to lack of expertise and skills, but also owing to shortage of capital and week telecommunication infrastructure.
} 
outsourcing were provided in more than 120 countries in the world ${ }^{12}$. India ${ }^{13}$, Brazil, Russia and China are considered the most attractive sourcing destinations for ITO and BPO. This is mainly because of the scale of services, available skills, and the maturity achieved with regard to offshoring activities. Forecasts, however, indicate that in the next few years these countries' share will be decreasing in relation to other expanding locations, including Central and Eastern Europe ${ }^{14}$ (Oshri, Kotlarsky \& Willcocks, 2011).

In the last few years, the CEE countries have become an important location for services offshoring, not only from a European perspective, but also worldwide; there has been significant growth in the participation of this region in the global services offshoring market. At the moment, the CEE countries have approximately an $8 \%$ share of global services offshoring. Currently, there are about 1000 centres with foreign capital operating in business and IT-related sectors, employing 270-300 thousand individuals with $20 \%$ yearly growth (Górecki et al., 2013). A distinct majority of them are investments by companies from Western Europe. ${ }^{15}$ Major European corporations, after targeting Asian locations ${ }^{16}$, are now looking towards CEE to meet their nearshoring ${ }^{17}$ requirements. V4 countries, offering closer proximity to the supplier, fewer time zone differences, and lower transaction costs, are especially significant nearshore destinations for Western European clients. ${ }^{18}$

In terms of ITO/BPO services, the market is growing as CEE countries become more westernised and the quality of life in these countries moves towards those of Western European countries. However, CEE may be more attractive for BPO than ITO because they provide excellent general education, but do not graduate IT students at anywhere near the pace that India does. Furthermore, local CEE demand for software and ITrelated products and services is expected to continue growing, which means that Western European companies already present in the region are able to take advantage of their good access to such markets (Oshri, Kotlarsky \& Willcocks, 2011).

The CEE offshoring industry is also well-positioned to fill demand for higher valueadded services, as the recent growth in offshored R\&D and engineering services in the region indicates. Even now, CEE service centres typically compete in terms of skills and not in terms of scale, offering higher value-added services than competitors in other countries that focus more on high-volume transactional processes. Globally, there is growing demand for more sophisticated services such as R\&D and big data analytics. CEE offshoring centres may also be able to compete for relatively untapped offshoring

\footnotetext{
${ }^{12}$ As per The Hackett Group there are 4900 service centres operating globally, with $52 \%$ of them located in Europe.

${ }^{13}$ The position of leader is still held by India, with approximately $40 \%$ of the market.

${ }^{14}$ CEE offshoring industry is growing at twice the rate of India's sector (McKinsey Global Institute, 2013).

${ }^{15}$ Companies from Germany, United Kingdom, Austria, Norway, Sweden and Netherlands most frequently opt to move their services to nearshore locations, rather than somewhere offshore.

${ }^{16}$ The costs of offshoring to traditional locations, such as China and India, have exploded in recent years and are starting to match the costs of many CEE countries.

${ }^{17}$ Nearshoring means relocating service activities to a foreign, lower-cost country that is relatively close in distance and within the same continent or time zone.

${ }^{18}$ The study of Carmel \& Abbott (2007) identifies three major global nearshore clusters: one cluster of 20 countries surrounds North America, and another 27 countries (including CEE) form a cluster around Western Europe. The third smaller cluster lies in East Asia.
} 
markets, such as public sector services, health, media, and utilities. There is also growing demand from small and medium-sized enterprises, which are expected to drive $40 \%$ of increasing growth through 2020 (McKinsey Global Institute, 2013).

Another option for CEE offshoring companies is to move up the value chain by positioning themselves as the coordinators of a broad network of offshoring services for clients. The CEE centres would experience the evolution from transaction centre to centres of excellence, from servicing single processes to influencing and transforming global ones, from service provision for individual European countries to multicultural melting pots.

Among the CEE countries, Poland and the Czech Republic stand out as having notable market potential. Poland is attractive as both a captive and outsourcing location. It is also a strong nearshore destination for Western European. Current estimates state that there are 400 service centres ${ }^{19}$, belonging to nearly 300 investors and employing 110000 individuals $^{20}$ (Górecki et al., 2013). The range of services is increasing in terms of the types of processes, geographic scope and market sectors. Simple transactions are being displaced by complicated tasks requiring high employee competence and knowledge.

Poland's offshoring industry has enjoyed great support from the local and national governments. It also benefits from country's size and resources. The Polish educational system is closer in quality to EU-15 schools than those of other nations in the region, and its large population provides a deep talent pool. Poland has also withstood the crisis better than countries such as Hungary, and it still has significantly lower labour costs than the Czech Republic, Slovakia, and Hungary. As a result, it continues to attract new business, winning 40 out of 46 large offshoring deals in the region in 2012 (McKinsey Global Institute 2013).

The Czech Republic also has a strong position in the CEE offshoring market ${ }^{21}$. It is in second place after Poland, offering the most attractive education system, and data and intellectual property security and privacy among all the CEE countries. The latest research shows that on the Czech market there is a minimum of 200 centres which employ around 50000 individuals. The growth rate of the industry has accelerated during last 3 years and next year is expected to increase by over $20 \%$ (Drygała \& Colantonio, 2013).

While nations worldwide increasingly compete for a share of this significant and rapidly increasing offshore market, the V4 countries must continue to work at staying on the CEE podium, regarding successes achieved in other CEE countries and the increasing competition in terms of governmental incentives or infrastructure.

\footnotetext{
19 Including shared service centres, business process and IT outsourcing centres, research and development centres (R\&D).

${ }^{20}$ The Polish offshoring market is growing at an average rate of $20 \%$ per year.

${ }^{21}$ It is important to note that the high level of investment into the offsorable service sector in the Czech Republic is linked to the fact that in general, the Czech Republic continues to be a CEE leader in terms of FDI.
} 


\section{CONCLUSIONS}

The tradability revolution in services has resulted in a rapid surge of transfers in service activities. Within the CEE region, especially the V4 countries could use their potential to reach a strong position on the global map of services offshoring. These countries achieved the highest levels of progress in terms of modernising their service industries and witnessed a rapid shift towards services. Trade statistics confirm the assumption that an expanding export in other business services and computer and information services is associated with the growing importance of the V4 countries as offshoring locations. During the last decade, the CEE particularly benefited from the worldwide structural shift towards service-based FDI. The region shows growing potential and might attract many investors looking to establish shared service or contact centres, as well as more recent initiatives in the form of knowledge process offshoring or research \& development.

In the last few years, the CEE economies have developed a globally competitive offshoring industry. The region built its attractiveness primarily around its nearshoring advantages ${ }^{22}$ arising from the combination of the availability of skilled labour and strong language skills, low costs, favourable business and stable political environments, welldeveloped infrastructure, and geographical and cultural proximity to Western Europe.

It seems that for all the V4 countries, their biggest problems are related to the competition of the remaining CEE states, as they all try to further penetrate the nearby Western European market. In the CEE region, many countries are in the position to emulate V4's offshoring success. Bulgaria and Romania are close to Poland in terms of employee qualifications; these countries are also characterised by significant cost advantages in comparison to Western Europe and share cultural and geographic proximity to major European customers. Despite all this, in the coming decade there will be opportunities for the V4 countries, individually and as a group, to build on their past successes in exports.

\section{REFERENCES}

Drygała, R., \& Colantonio, A. (2013). Business Services Sector in Czech Republic, Association of Business Service Leaders, Retrieved on January 24, 2014, from http://www.absl.cz/docs/ 2013-10-17-conference/absl-report-2013.pdf

Carmel, E., \& Abbott, P. (2007). Why nearshore means that distance matters. Communications of the ACM, 50(10), 40-46.

Everest Research Institute (2010). Europe's Global Sourcing Market: Trends, Growth and Prospects, Everest Group, Retrieved on January 24, 2014, from https://research.everestgrp.com/Produc t/ITIDA-Everest\%20Europe\%20Global\%20Sourcing/Europe-s-Global-Sourcing-Market-Trend

\footnotetext{
${ }^{22}$ Nearshoring represents a major way in which CEE countries can compete with India for market share. Within this context, nearshore might be presented as a reaction to the main offshore destination - India, which is viewed as "farshore," a very distant destination, many hours to travel, many time zones away, and a very different culture.
} 
Fifekova, M., \& Hardy, J. (2010). Business Service Foreign Direct Investment in Central and Eastern Europe: trends, motives and impacts, The Economy And Society Trust, Retrieved on January 24, 2014, from http://www.czechinvest.org/data/files/fdi-project-report-1981-en.pdf

Gal, Z. (2013). Business \& Financial Services Offshoring in Central and Eastern Europe. In I.P. Kovacs, J. Scott, \& Z. Gal (Eds.), Territorial Cohesion in Europe (pp. 271-284). For the $70^{\text {th }}$ Anniversary of the Transdanubian Research Institute. Institute for Regional Studies, Centre for Economic and Regional Studies. Pecs: Hungarian Academy of Sciences.

Ghibutiu, A., \& Poladian, S. (2009). Global Sourcing of Services: How Well Are the New EU Members States Coping with the Challenges?. Romanian Journal of Economic Forcasting, 1, 123-135.

Górecki, J., Jasińska, M., Polkowski, M., \& Karpiesiuk, Ł. (2013). Sektor nowoczesnych usług biznesowych w Polsce, Warszawa: Association of Business Service Leaders.

Małuszyńska, E. (2013). Migracje i delokalizacje przedsiębiorstw. Poznań: Wydawnictwo Uniwersytetu Ekonomicznego w Poznaniu.

McKinsey Global Institute (2004). Offshoring: Is it a Win-Win Game, McKinsey Global Institute, Available from: <http://www.mckinsey.com/insights/employment_and_growth/offshoring _is_it_a_win-win_game>. [15 January 2014].

McKinsey Global Institute (2013). A new dawn: Reigniting growth in Central and Eastern Europe, McKinsey Global Institute, Retrieved on January 24, 2014, from http://www.mckinsey.com/ insights/employment_and_growth/offshoring_is_it_a_win-win_game

OECD (2005). OECD Information Technology Outlook 2004. Paris: Organisation for Economic Cooperation and Development.

Oshri, I., Kotlarsky, J., \& Willcocks, L.P. (2011). The Handbook of Global Outsourcing and Offshoring. London: Palgrave Macmillan.

Radło, M.J. (2006). Globalizacja, inwestycje bezpośrednie, delokalizacja, offshoring, outsourcing: podstawowe definicje. In: T. Kalinowski, \& M. Nowicki (Eds.), Delokalizacja w rozszerzonej Unii Europejskiej- perspektywa wybranych państw UE. Wnioski dla Polski, (pp. 9-17). Warszawa: Urząd Komitetu Integracji Europejskiej.

Sako, M. (2005). Outsourcing and Offshoring: Key Trends and Issues. Oxford: Oxford Said Business School.

Sass, M., \& Fifekova, M. (2011). Offshoring and outsourcing business service to Central and Eastern Europe: some empirical and conceptual considerations. European Planning Studies, 19(9), 1593-1609.

UNCTAD (2004). World Investment Report 2004: The Shift Towards Services. New York - Geneva: United Nations.

WTO (2005). World Trade Report 2005. Exploring the Links Between Trade, Standards and the WTO. Geneva: World Trade Organization.

WTO (2013). International Trade Statistics 2013, Geneva: World Trade Organization. 


\section{Author}

\section{Magdalena Rudnicka}

Assistant Professor at the Department of International Economics at Wrocław University of Economics. Her research activity is focused on the study of international economic relations. She has written and published papers concerning many various aspects of this field involving international trade policy, Polish foreign exchange law and international trade in services. Furthermore, since 2006 she has conducted teaching classes on the subjects of international economic relationships, foreign trade, international settlements and international finance.

\section{Correspondence to:}

Magdalena Myszkowska, PhD

Wrocław University of Economics

Faculty of Economic Sciences

Department of International Economics

ul. Komandorska 118/120, 53-345 Wrocław, Poland

magdalena.myszkowska@ue.wroc.pl 